\title{
THE USE OF MUTTON IN SAUSAGE PRODUCTION
}

\author{
Juraj Čuboň, Peter Haščík, Peter Herc, Lukáš Hleba, Miroslava Hlebová, \\ Nikoleta Šimonová, Ondřej Bučko
}

\begin{abstract}
The work analyzes the quality of sausage with mutton. The proportion of individual commodities was as follows $40 \%$ sheep

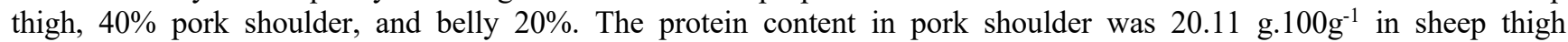

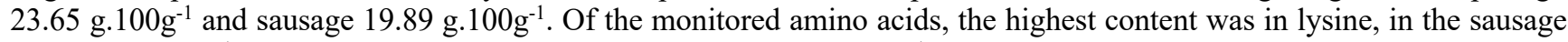
was $1.9 \mathrm{~g} .100 \mathrm{~g}^{-1}$ and of the raw materials in the belly $2.1 \mathrm{~g} .100 \mathrm{~g}^{-1}$. We also found a higher proportion of leucine $1.7 \mathrm{~g} .100 \mathrm{~g}^{-1}$ in both sausage and sheep thighs. The arginine content in the sausage was also high $1.39 \mathrm{~g} .100 \mathrm{~g}^{-1}$. We found a high content of palmitic acid in the pork shoulder of $24.38 \mathrm{~g} .100 \mathrm{~g}^{-1}$ FAME. The content of palmitic acid in sheep meat was 24.32 g. $100 \mathrm{~g}^{-1}$ FAME and in sausage 24.16 g. $100 \mathrm{~g}^{-1}$ FAME. The content of stearic acid in the pork shoulder was

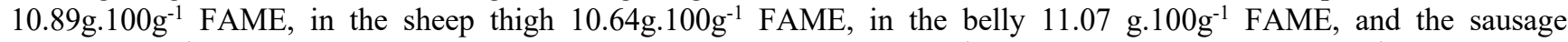
10.92 g. $100 \mathrm{~g}^{-1}$ FAME. The MDA content in sheep meat was $0.185 \mathrm{mg} . \mathrm{kg}^{-1}$, in pork shoulder $0.141 \mathrm{mg}^{\mathrm{kg}} \mathrm{kg}^{-1}$, in pork belly $0.22 \mathrm{mg} \cdot \mathrm{kg}^{-1}$ and in sausage on the day of production $0.45 \mathrm{mg} \cdot \mathrm{kg}^{-1}$. On the $30^{\text {th }}$ day, the MDA content was in the sausage $0.78 \mathrm{mg} \cdot \mathrm{kg}^{-1}$. The high MDA content of the sausage was probably most influenced by the technological process, as all raw materials, because there was a lower MDA content.
\end{abstract}

Keywords: meat; sausage; fatty acids; malondialdehyde

\section{INTRODUCTION}

According to Commission Delegated Regulation (EU) 2017/1182, sheep carcasses to 1 year old are classified as lambs and adult sheep over 1 year old. The meat of adult sheep has very good sensory and technological properties, but the consumer perceives it to a certain extent negatively. If the meat is used in meat products, the producer must declare his content in the final product.

In Slovakia, pork is the most preferred type of meat, whose chemical composition may vary depending on the topographic origin. In pork, depending on the cut parts, the protein content is $9 \%-20 \%$ (Poráčová et al., 2017). Meat quality is defined as a combination of basic meat characteristics (Čuboň et al., 2017).

It is the first sign that the consumer notices and thanks to which he also makes a decision. The color of the meat is determined by the state of myoglobin, oxymyoglobin is bright red and metmyoglobin is brown (Ning et al., 2019).

The color of the cut ripened pork is pale pink and its taste depends mainly on various factors such as the age of the animal and its method of feeding. The meat of younger animals is paler and suitable for cutting. Older individuals have dark red meat and are suitable for the production of mainly durable meat products (Holland et al., 1991).

Pork has an optimal content of unsaturated fatty acids and also shows a good representation of essential substances and minerals. From a nutritional point of view, it is an important source of animal protein (Fuastman and Suman, 2017).

In lean lamb meat contains about $20-25 \%$ of proteins, while in heat-treated meat their content is $28-36 \%$ because the water content in the meat is reduced and nutrients are concentrated during culinary processing. Protein digestibility is high, approximately $94 \%$ compared to beans $(78 \%)$ or wheat $(86 \%)$. Lamb meat contains all the essential amino acids (Krishtafovich et al., 2016). According to Williams (2007), the amino acids glutamine and glutamic acid are found in sheep meat in the largest amounts than in other types of meat. Other higher amino acids include arginine, alanine, and aspartic acid. The tryptophan content is highly variable depending on age and muscle area Crăciun et al. (2012).

Sheepmeat contains saturated, monounsaturated, and polyunsaturated fatty acids, the content of which is optimal from a technological point of view and the point of view of a healthy diet (Krishtafovich et al., 2016).

Sheep grazed on native pastures have a polyunsaturated fatty acid content of $200-500 \mathrm{mg} .100 \mathrm{~g}^{-1}$ of fresh meat, such meat is considered an appropriate source of polyunsaturated fatty acids (Cabrera and Saadoun, 2014).

Fat oxidation during meat processing and storage is influenced by lipid content and composition (Tsikas, 2017). Fat oxidation increases with the amount of fat and mainly depending on the ratio between PUFA and SFA (Bertolín 
and Blanco, 2019). Lipid oxidation is a complex chain reaction process that results in the presence of reactive oxygen species, such as the superoxide radical anion. The peroxide non-radical anion can be produced by enzymes and non-enzymatic chemical reduction of molecular oxygen (Cunha et al., 2018). Reactive oxygen species react with various biomolecules, e.g. PUFAs, forming aldehydes, ketones, acids, alcohols, and hydrocarbons that cause undesirable changes in structure, taste, and also color. Finally, they reduce the quality of the product until it becomes unfit for human consumption (Jung et al., 2016).

Sensory and nutritional value are greatly affected by lipid oxidation, which is an undesirable manufacturing process. Oxidation causes the formation of aldehydes and ketones, which result in an unpleasant taste and smell of meat (Bobko et al., 2015).

Lipid oxidation results in the formation of aldehydes. The most common aldehyde produced by damaging the polyunsaturated fatty acids is malondialdehyde (MDA). It is a simple alkandial derived from malonic acid (Čuboň et al., 2019).

Currently, one of the markers used to determine the degree of lipid oxidation in meat and meat products is malondialdehyde, which is formed as a secondary product of lipid oxidation. The MDA content of meat is determined using thiobarbituric acid reactants (TBARS) (Tsikas, 2017).

Meat and meat products are susceptible to quality deterioration due to their rich nutritional composition (Bobko et al., 2017).

Jung et al. (2016) and Bertolín and Blanco (2019) report that TBARS is used to determine the degree of lipid oxidation in meat and meat products.

The excessive content of biogenic amines causes undesirable sensory properties. From a hygienic point of view, biogenic amines serve as indicators degree of food spoilage (Čuboň et al., 2015).

\section{Scientific Hypothesis}

The aim of the work was the analysis of the basic chemical composition, fatty acids, amino acid content, and fat oxidation in sausage with the proportion of mutton and the raw material.

\section{MATERIAL AND METHODOLOGY \\ Samples}

Pork shoulder, pork belly, sheep thigh, sausage.

The individual commodities were used in the product as follows: $40 \%$ lamb thigh, $40 \%$ pork shoulder, and belly $20 \%$. The meat was cut into smaller pieces and then minced on a grinder with $3 \mathrm{~mm}$ holes. Subsequently, the ingredients were added and the work was mixed thoroughly. The meat work lasted several tens of minutes to 1 hour and then stuffed into pork intestines. The sausages were smoked in a traditional smokehouse with cold smoke.

Ingredients per $10 \mathrm{~kg}$ of sausage: salt $20 \mathrm{dkg}$, ground red pepper $100 \mathrm{~g}, 5$ head garlic, ground cumin $25 \mathrm{~g}$, cumin whole $25 \mathrm{~g}$, ground black pepper $28 \mathrm{~g}$.

\section{Laboratory Methods}

Sausage samples were analyzed by FT-IR analysis (Nicolet 6700) of chemical composition, $100 \mathrm{~g}$ of sausages were taken. Subsequently, the samples were homogenized and analyzed. The method is based on the absorption of infrared radiation during the passage through the sample, during which changes in the rotational vibrational energy states of the molecule take place depending on changes in the dipole moment of the molecule. The resulting infrared spectrum is the functional dependence of energy, mostly expressed as a percentage of transmittance or units of absorbance at the wavelength of the incident radiation. The results of this analysis are given in g. $100 \mathrm{~g}^{-1}$. Selected analyzed parameters of chemical composition were: content of proteins, water, lipids, omega 3 and 6 fatty acids, cholesterol, essential and selected non-essential amino acids, the content of selected monounsaturated fatty acids (MUFA), polyunsaturated fatty acids (PUFA), saturated fatty acids (SFA) and their total content in sausages.

Oxidative stability analysis by determining the concentration of malondialdehyde as the final oxidation product of the fat component of rabbit meat by the TBA (thiobarbiturate) method was performed on days 1 and 30 of sausage storage. The principle of the method is the spectrophotometric determination of the color complex, which is formed by the reaction of 2 molecules of TBA and the content of malondialdehyde (MDA) at a wavelength of $532 \mathrm{~nm}$.

Approach:

- Weigh $1.5 \mathrm{~g}$ of the ground sample into a $50 \mathrm{~mL}$ centrifuge tube,

- addition of $1 \mathrm{~mL}$ EDTA (complexing agent) + mixing,

- add $5 \mathrm{~mL}$ of $0.8 \%$ BHT + mix,

- before homogenization, add $8 \mathrm{~mL}$ of $5 \%$ TCA,

- homogenization of 30 solutions $10,000 \mathrm{rpm}$,

- sample standing for 10 minutes followed by centrifugation for 5 minutes $\left(3,500 \mathrm{x} \mathrm{g}, 4^{\circ} \mathrm{C}\right)$,

- removal of the hexane layer after centrifugation and subsequent filtration of the samples,

- make up to $10 \mathrm{~mL}$ with $5 \%$ TCA,

- add $1 \mathrm{~mL}$ TBA to $4 \mathrm{~mL}$ sample,

- incubation in a water bath for $90 \mathrm{~min}$ at $70^{\circ} \mathrm{C}$,

- cooling and tempering to room temperature $45 \mathrm{~min}$,

- extinction of samples for UV-VIS spectrophotometry at a wavelength of $532 \mathrm{~nm}$,

- recalculation of the obtained data and determination of the concentration of malondialdehyde in mg.kg-1 (Marcinčák et al., 2005).

\section{Statistical Analysis}

The measured results of the analyzes were varied and statistically processed by SAS (2008) 9.3 Enhanced Logging Facilities, Cary, NC: SAS Institute Inc., 2008. We also processed the data of the analyzed parameters in Microsoft Excel. 


\section{RESULTS AND DISCUSSION}

Table 1 shows the results of the basic chemical component of pork shoulder, sheep's thigh, pork belly, and sausage. The

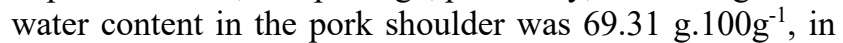
the sheep's thigh $73.34 \mathrm{~g} .100 \mathrm{~g}^{-1}$, in the belly only 60.91 g. $100 \mathrm{~g}^{-1}$ and in the sausage, the content was lower $\left(62.34100 \mathrm{~g}^{-1}\right)$. The protein content in the pig's shoulder was

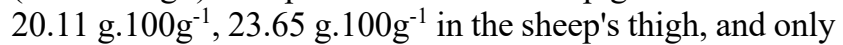
12.6 g. $100 \mathrm{~g}^{-1}$ in the belly. We found in sausage a protein content of 19.89 g. $100 \mathrm{~g}^{-1}$. However, the fat content was

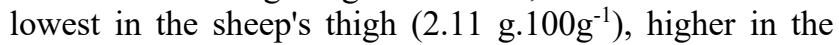
sausage 14.04 g. $100 \mathrm{~g}^{-1}$, and highest in the pig belly 24.6 g. $100 \mathrm{~g}^{-1}$. Consistent with our results Nowak et al. (2016) report a water content of $62.46 \mathrm{~g} .100 \mathrm{~g}^{-1}$, a fat content of $20.02 \mathrm{~g} .100 \mathrm{~g}^{-1}$, and lower protein content of

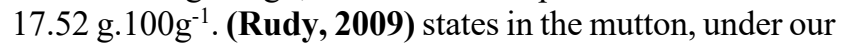
results, in the first water content $72.80 \mathrm{~g} .100 \mathrm{~g}^{-1}$, fat content 3.60 g. $100 \mathrm{~g}^{-1}$, and protein $21.50 \mathrm{~g} .100 \mathrm{~g}^{-1}$. Bertolín et al. (2018) in contrast to our results report a higher cholesterol content of $0.69 \mathrm{~g} .100 \mathrm{~g}^{-1}$ in sheep meat.

Of all the monitored amino acids (Table 2), the highest proportion was the amino acid lysine, in sausage 1.9 g. $100 \mathrm{~g}^{-1}$, of the raw materials the highest content in the belly was $2.1 \mathrm{~g} \cdot 100 \mathrm{~g}^{-1}$. We also found a higher proportion in the leucine content of $1.7 \mathrm{~g} .100 \mathrm{~g}^{-1}$ in both sausage and lamb thighs. The arginine content in the sausage was also high at 1.39 g. $100 \mathrm{~g}^{-1}$.

Cheng et al. (2017) report a lower lysine content in pork Longissimus thoracis $0.98 \mathrm{~g} .100 \mathrm{~g}^{-1}$ compared to our results. Marti-Quijal et al. (2019) in turn report a lower lysine content of 1.36 g. $100 \mathrm{~g}^{-1}$ in the sausage. Lower lysine content in mutton $\left(0.79\right.$ g. $\left.100 \mathrm{~g}^{-1}\right)$ is reported by Huang et al. (2020).

Cheng et al. (2017) and Huang et al. (2020) compared to our results report a lower methionine content in pork $0.28 \mathrm{~g} .100 \mathrm{~g}^{-1}$ and mutton $0.33 \mathrm{~g} .100 \mathrm{~g}^{-1}$.

Cheng et al. (2017) found a lower threonine content of 0.70 g. $100 \mathrm{~g}^{-1}$ in pork Longissimus thoracis. Also, Huang et al. (2020) also found a lower threonine content of 0.550 g. $100 \mathrm{~g}^{-1}$, but Marti-Quijal et al. (2019) found a lower threonine content of $\left(0.69 \mathrm{~g} .100 \mathrm{~g}^{-1}\right)$ in pork sausage compared to our results.

Jia et al. (2019) found out a higher content of isoleucine in pork $\left(0.91 \mathrm{~g} .100 \mathrm{~g}^{-1}\right)$ compared to our results. On the other hand, Huang et al. (2020) report a lower isoleucine content $\left(0.44\right.$ g. $\left.100 \mathrm{~g}^{-1}\right)$. Marti-Quijal et al. (2019) report a lower isoleucine content of $0.73 \mathrm{~g} .100 \mathrm{~g}^{-1}$ in the sausage compared to our results.

Higher content of phenylalanine in pork than 1.37 g. $100 \mathrm{~g}^{-1}$ was found by Jia et al. (2019). Marti-Quijal et al. (2019) found in the sausage its lower phenylalanine content 0.662 g. $100 \mathrm{~g}^{-1}$ compared to our results. Also, Huang et al. (2020) found a lower phenylalanine meat mutant content of $0.49 \mathrm{~g} .100 \mathrm{~g}^{-1}$ compared to our results.

A lower histidine content of $0.6 \mathrm{~g} .100 \mathrm{~g}^{-1}$ in pork was found by Jia et al. (2019). Similarly, Huang et al. (2020) found a lower content of histidine $\left(0.62 \mathrm{~g} .100 \mathrm{~g}^{-1}\right)$ compared to our results, but in mutton meat. Marti-Quijal et al. (2019) found a lower content of histidine in the sausage

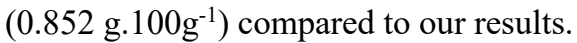

Table 3 shows the content of fatty acids in the raw material and sausage, the highest proportion of all fatty acids is oleic acid, of which 36.63 g. $100 \mathrm{~g}^{-1}$ FAME in pork shoulder. Aali et al. (2017) report a higher oleic acid content in sheep longissimus dorsi (38.30 g. $100 \mathrm{~g}^{-1}$ FAME) compared to our results. The content of oleic acid in the belly was up to 60.33 g. $100 \mathrm{~g}^{-1}$ FAME and in the sausage $55.52{\mathrm{~g} .100 \mathrm{~g}^{-1}}^{-1}$ FAME. Compared to our results, Cruxen et al. (2018) found out lower oleic acid content in mutton sausage (41.25g. $100 \mathrm{~g}^{-1}$ FAME).

We also found high content in the proportion of palmitic acid, in pork shoulder 24.38 g. $100 \mathrm{~g}^{-1}$ FAME. Consistent with our results Kim et al. (2009) found out palmitic acid content in pork $24.17 \mathrm{~g} .100 \mathrm{~g}^{-1}$ FAME. We found a palmitic acid content of 24.32 g. $100 \mathrm{~g}^{-1}$ FAME in the sheep's thigh. Compared to our results Chikwanha et al. (2018) found out lower content of palmitic acid in sheep meat $\left(22.2 \mathrm{~g} 100 \mathrm{~g}^{-1}\right.$ FAME). The palmitic acid content of the sausage was 24.16 g. $100 \mathrm{~g}^{-1}$ FAME, the lower content $\left(23.03 \mathrm{~g}^{-100 \mathrm{~g}^{-1}}\right.$ FAME) is reported by Cruxen et al. (2018).

Table 1 Chemical composition of raw material and sausage (g. $\left.100 \mathrm{~g}^{-1} \pm S D\right)$.

\begin{tabular}{lcccc}
\hline \multicolumn{1}{c}{ Parameter } & Pork shoulder & Sheep thigh & Pork belly & Sausage \\
\hline Water & $69.31 \pm 1.21$ & $73.34 \pm 1.03$ & $60.91 \pm 1.53$ & $62.34 \pm 2.14$ \\
Protein & $20.11 \pm 0.47$ & $23.65 \pm 1.14$ & $12.60 \pm 0.54$ & $19.89 \pm 2.19$ \\
Fat & $8.93 \pm 1.01$ & $2.11 \pm 0.4$ & $24.60 \pm 1.85$ & $14.04 \pm 4.67$ \\
Cholesterol & $0.61 \pm 0.16$ & $0.51 \pm 0.08$ & $2.12 \pm 0.17$ & $1.65 \pm 0.54$ \\
\hline
\end{tabular}

Table 2 Amino acid content of raw material and sausage $\left(\mathrm{g} .100 \mathrm{~g}^{-1} \pm S D\right)$.

\begin{tabular}{lcccc}
\hline \multicolumn{1}{c}{ Parameter } & Pork shoulder & Sheep thigh & Pork belly & Sausage \\
\hline Protein & $20.11 \pm 0.47$ & $23.65 \pm 0.14$ & $12.60 \pm 0.54$ & $19.89 \pm 2.19$ \\
Lyzin & $1.71 \pm 0.57$ & $1.73 \pm 0.28$ & $2.1 \pm 0.37$ & $1.90 \pm 0.05$ \\
Leucin & $1.57 \pm 0.09$ & $1.7 \pm 0.25$ & $1.71 \pm 0.33$ & $1.7 \pm 0.05$ \\
Metionin & $0.66 \pm 0.23$ & $0.67 \pm 0.07$ & $0.99 \pm 0.12$ & $0.82 \pm 0.01$ \\
Treonin & $0.81 \pm 0.24$ & $0.79 \pm 0.12$ & $0.61 \pm 0.14$ & $0.89 \pm 0.04$ \\
Valin & $0.82 \pm 0.19$ & $0.82 \pm 0.09$ & $0.82 \pm 0.11$ & $0.79 \pm 0.05$ \\
Izoleucin & $0.78 \pm 0.27$ & $0.79 \pm 0.14$ & $0.74 \pm 0.17$ & $0.85 \pm 0.03$ \\
Histidin & $0.86 \pm 0.31$ & $0.82 \pm 0.11$ & $0.81 \pm 0.14$ & $0.85 \pm 0.06$ \\
Fenylalanin & $0.81 \pm 0.25$ & $0.82 \pm 0.12$ & $0.77 \pm 0.6$ & $0.88 \pm 0.03$ \\
Cystein & $0.27 \pm 0.08$ & $0.25 \pm 0.02$ & $0.29 \pm 0.01$ & $0.41 \pm 0.02$ \\
Arginin & $1.273 \pm 0.42$ & $1.29 \pm 0.12$ & $1.20 \pm 0.18$ & $1.39 \pm 0.04$ \\
\hline
\end{tabular}


Table 3 Content of fat $\left(\mathrm{g} .100 \mathrm{~g}^{-1} \pm S D\right)$ and fatty acids (g. $100 \mathrm{~g}^{-1} \pm S D$ FAME) in the raw material and sausage.

\begin{tabular}{lcccc}
\hline \multicolumn{1}{c}{ Parameter } & Pork shoulder & Sheep thigh & Pork belly & Sausage \\
\hline Fat & $8.93 \pm 1.01$ & $2.11 \pm 0.4$ & $24.60 \pm 1.85$ & $14.04 \pm 4.67$ \\
3 omega FA & $0.53 \pm 0.01$ & $0.54 \pm 0.26$ & $0.85 \pm 0.11$ & $0.7 \pm 0.04$ \\
6 omega FA & $9.5 \pm 1.02$ & $11.4 \pm 0.81$ & $5.27 \pm 1.9$ & $1.17 \pm 0.41$ \\
Esential FA & $8.43 \pm 0.9$ & $9.13 \pm 1.12$ & $6.38 \pm 1.91$ & $1.08 \pm 0.75$ \\
MUFA & $49.62 \pm 2.02$ & $47.78 \pm 0.79$ & $69.93 \pm 1.94$ & $60.92 \pm 1.61$ \\
PUFA & $12.1 \pm 1.07$ & $14.98 \pm 1.03$ & $3.02 \pm 1.36$ & $8.51 \pm 0.98$ \\
SAFA & $34.21 \pm 2.21$ & $33.52 \pm 1.31$ & $26.49 \pm 1.05$ & $28.24 \pm 2.06$ \\
C12:0 Lauric A. & $0.12 \pm 0.03$ & $0.11 \pm 0.003$ & $0.02 \pm 0.01$ & $0.06 \pm 0.01$ \\
C14:0 Myristic A. & $1.35 \pm 0.02$ & $1.38 \pm 0.04$ & $1.23 \pm 0.02$ & $1.31 \pm 0.09$ \\
C16:0 Palmit A. & $24.38 \pm 1.4$ & $24.32 \pm 0.31$ & $24.01 \pm 0.1$ & $24.16 \pm 0.18$ \\
C17:0 Heptadecanoid A. & $0.31 \pm 0.03$ & $0.30 \pm 0.03$ & $0.12 \pm 0.02$ & $0.19 \pm 0.04$ \\
C18:0 Stearic A. & $10.89 \pm 0.03$ & $10.64 \pm 0.31$ & $11.07 \pm 0.09$ & $10.92 \pm 0.17$ \\
9c-C18:1 Oleic A. & $36.63 \pm 6.1$ & $31.37 \pm 5.7$ & $60.33 \pm 4.43$ & $55.52 \pm 4.97$ \\
11c/15t-C18:1 Vakcen A. & $4.78 \pm 0.1$ & $4.91 \pm 0.18$ & $4.35 \pm 0.06$ & $4.58 \pm 0.05$ \\
C18:2 n-6 Linoleic A. & $6.94 \pm 1.02$ & $8.66 \pm 0.66$ & $1.64 \pm 1.29$ & $3.24 \pm 0.51$ \\
9c,11t 18:2 Conjugated Linoleic A. & $0.13 \pm 0.02$ & $0.13 \pm 0.01$ & $0.06 \pm 0.01$ & $0.09 \pm 0.02$ \\
C18:3 n-3 Linolenic A. & $0.15 \pm 0.03$ & $0.17 \pm 0.03$ & $0.34 \pm 0.1$ & $0.16 \pm 0.02$ \\
C20:1 Eikozenoic A. & $0.51 \pm 0.17$ & $0.54 \pm 0.11$ & $1.26 \pm 0.15$ & $0.99 \pm 0.12$ \\
C20:4 n6 Arachidonic A. & $1.85 \pm 0.41$ & $1.82 \pm 0.21$ & $0.17 \pm 0.11$ & $0.77 \pm 0.26$ \\
C20:5 n3 Eikozapentaenoic A. & $0.097 \pm 0.02$ & $0.1 \pm 0.02$ & $0.01 \pm 0.00$ & $0.04 \pm 0.01$ \\
C22:5 n-3 Dokozapentaenoic A. & $0.13 \pm 0.01$ & $0.14 \pm 0.02$ & $0.11 \pm 0.00$ & $0.12 \pm 0.01$ \\
C22:6 n-3 Dokozahexaenoic A. & $0.03 \pm 0.03$ & $0.04 \pm 0.01$ & $0.04 \pm 0.00$ & $0.04 \pm 0.003$ \\
\hline & & & &
\end{tabular}

Table 4 MDA content in raw material and sausage on the first and thirtieth day after production (mg.kg-1 $\pm S D)$.

\begin{tabular}{lccccc}
\hline \multirow{2}{*}{ Parameter } & \multirow{2}{*}{ Pork shoulder } & \multirow{2}{*}{ Sheep thing } & \multirow{2}{*}{ Pork belly } & \multicolumn{2}{c}{ Sausage } \\
\cline { 4 - 6 } & & & 1-st day storage & 30-th days storage \\
\hline MDA & $0.141 \pm 0.03$ & $0.185 \pm 0.053$ & $0.22 \pm 0.03$ & $0.45 \pm 0.022$ & $0.78 \pm 0.08$ \\
\hline
\end{tabular}

The content of stearic acid in the pork shoulder was 10.89 g. $100 \mathrm{~g}^{-1}$ FAME, in the sheep's thigh 10.64 g. $100 \mathrm{~g}^{-1}$ FAME, in the belly 11.07 g. $100 \mathrm{~g}^{-1}$ FAME, and in the sausage 10.92 g. $100 \mathrm{~g}^{-1}$ FAME. Huang et al. (2020) report a higher content of stearic acid in pork (11.07 g. $100 \mathrm{~g}^{-1}$ FAME) compared to our results. In contrast to our results, Chikwanha et al. (2018) found out higher content of stearic acid in mutton (18.1 g. $100 \mathrm{~g}^{-1}$ FAME) and Marti-Quijal et al. (2019) slightly higher values in sausage $13.51{\mathrm{~g} .100 \mathrm{~g}^{-1}}^{-1}$ FAME.

Cheng et al. (2017) report an almost identical myristic acid content in pork of $1.44 \mathrm{~g} .100 \mathrm{~g}^{-1}$ FAME compared to our values of 1.35 g. $100 \mathrm{~g}^{-1}$ FAME in pork shoulder and 1.31 g. $100 \mathrm{~g}^{-1}$ FAME in sausage. Higher content of myristic acid in the mutton 3.3 g. $100 \mathrm{~g}^{-1}$ FAME was found by Chikwanha et al. (2018) compared to our results 1.38 g. $100 \mathrm{~g}^{-1}$ FAME.

The content of eicosenic acid in the sausage was 0.99 g. $100 \mathrm{~g}^{-1}$ FAME, in the pork shoulder 0.51 g. $100 \mathrm{~g}^{-1}$ FAME, in the belly 1.24 g. $100 \mathrm{~g}^{-1}$ FAME and the sheep's thigh 0.54 g. $100 \mathrm{~g}^{-1}$ FAME. Kim et al. (2009) found a lower content of eicosenic acid (0.35 g. $100 \mathrm{~g}^{-1}$ FAME) in pork compared to our results and also Chikwanha et al. (2018) in mutton meat 0.45 g. $100 \mathrm{~g}^{-1}$ FAME. Feng et al. (2020) found a lower content of eicosenic acid in sausage (2.0 g. $100 \mathrm{~g}^{-1}$ FAME).

The content of docosahexaenoic acid in the pig's shoulder was 0.03 g. $100 \mathrm{~g}^{-1}$ FAME, in the sheep's thigh, in the belly and sausage was equally 0.04 g. $100 \mathrm{~g}^{-1}$ FAME. Chikwanha et al. (2018) reported up to $0.15 \mathrm{~g} \cdot 100 \mathrm{~g}^{-1}$ FAME in comparison with our results in mutton meat, in contrast to Cruxen et al. (2018) in sausage 0.09 g. $100 \mathrm{~g}^{-1}$ FAME.
The highest MUFA content $69.93 \mathrm{~g} \cdot 100 \mathrm{~g}^{-1}$ FAME in the belly was then in pork shoulder $49.62 \mathrm{~g} .100 \mathrm{~g}^{-1} \mathrm{FAME}$, in mutton 47.78 g. $100 \mathrm{~g}^{-1}$ FAME, and sausage $60,92{\mathrm{~g} .100 \mathrm{~g}^{-1}}^{-1}$

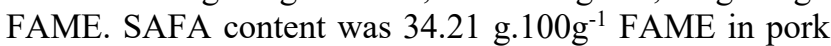
shoulder, 33.52 g. $100 \mathrm{~g}^{-1}$ FAME in mutton, and only 28.24 g. $100 \mathrm{~g}^{-1}$ FAME in sausage. The PUFA content in the mutton was 14.98 g. $100 \mathrm{~g}^{-1}$ FAME, in the belly 3.02 , and the sausage 8.51 g. $100 \mathrm{~g}^{-1}$ FAME. Abdallah et al. (2020) found out similarly with our results the MUFA content in mutton 46.9 g. $100 \mathrm{~g}^{-1}$ FAME, while Cheng et al. (2017) report only 41.60 g. $100 \mathrm{~g}^{-1}$ FAME in pork and Marti-Quijal et al. (2019) in sausage 48.84 g. $100 \mathrm{~g}^{-1}$ FAME. Cheng et al. (2017), in contrast to our results, found a lower PUFA content of $15.14 \mathrm{~g} .100 \mathrm{~g}^{-1} \mathrm{FAME}$, and compared to our study higher SAFA content in pork 39.99 g. $100 \mathrm{~g}^{-1}$ FAME identically also Abdallah et al. (2020) found out a higher SAFA content in mutton 36.7 g. $100 \mathrm{~g}^{-1}$ FAME.

The content of omega $3 \mathrm{FA}$ was highest in the belly 0.85 , lowest in the pork shoulder 0.53, and the sausage 0.7 g. $100 \mathrm{~g}^{-1}$ FAME. Consistent with our results, Feng et al. (2020) found in mutton sausage omega 3 FA content 0.75 g. $100 \mathrm{~g}^{-1}$ FAME.

Table 4 shows the content of malondialdehyde (MDA) as an indicator of oxidative stability in pork shoulder, belly, and mutton on the day of production. In sausage on the first and thirtieth day after production. The MDA content in mutton was $0.185 \mathrm{mg} \cdot \mathrm{kg}^{-1}$, in pork shoulder $0.141 \mathrm{mg} \cdot \mathrm{kg}^{-1}$, in pork belly $0.22 \mathrm{mg} \cdot \mathrm{kg}^{-1}$ and in sausage on the day of production $0.45 \mathrm{mg} \cdot \mathrm{kg}^{-1}$. On day 30 , the MDA content was in the sausage $\left(0.78 \mathrm{mg} \cdot \mathrm{kg}^{-1}\right)$. In comparison with our results Marcinčák et al. (2005) found out lower MDA content in pork $0.1166 \mathrm{mg} \cdot \mathrm{kg}^{-1}$, also Reitznerová et al. 
(2017) found a lower content of MDA $\left(0.055 \mathrm{mg} \cdot \mathrm{kg}^{-1}\right)$. In sausage after ripening 1-month Šojić et al. (2015) found an MDA content of $0.520 \mathrm{mg} \cdot \mathrm{kg}^{-1}$. The high MDA content of the sausage was probably most influenced by the production process, as all raw materials had a lower MDA content.

\section{CONCLUSION}

The basic composition of sausage representation of individual ingredients. The lower water content was influenced by its content in the belly but also by the reduction during drying and smoking. The content of individual monitored amino acids corresponding to the raw material used. The SAFA content of the raw materials ranged from 26.49 to $34.21 \mathrm{~g} .100 \mathrm{~g}^{-1}$ FAME and is generally considered sufficient for fat oxidation. Our results confirmed the increased content of MDA. The high MDA content of the sausage was probably most influenced by the production process, as all raw materials had a lower MDA content.

\section{REFERENCES}

Aali, M., Moradi-Shahrbabak, H., Moradi-Shahrbabak, M., Sadeghi, M., Yousefi, A. R. 2017. Association of the calpastatin genotypes, haplotypes, and SNPs with meat quality and fatty acid composition in two Iranian fat- and thin-tailed sheep breeds. Small Ruminant Research, vol. 149, p. 40-51. https://doi.org/10.1016/j.smallrumres.2016.12.026

Abdallah, A., Zhang, P., Elemba, E., Zhong, Q., Sun, Z. 2020. Carcass characteristics, meat quality, and functional compound deposition in sheep fed diets supplemented with Astragalus membranaceus by-product. Animal Feed Science and Technology, vol. 259, p. 114346. https://doi.org/10.1016/j.anifeedsci.2019.114346

Bertolín, J. R., Joy, M., Blanco, M. 2019. Malondialdehyde determination in raw and processed meat products by UPLCDAD and UPLC-FLD. Food Chemistry, vol. 298, p. 125009. https://doi.org/10.1016/j.foodchem.2019.125009

Bertolín, J. R., Joy, M., Rufino-Moya, P. J., Lobón, S., Blanco, M. 2018. Simultaneous determination of carotenoids, tocopherols, retinol and cholesterol in ovine lyophilised samples of milk, meat, and liver and in unprocessed/raw samples of fat. Food Chemistry, vol. 257, p. 182188. https://doi.org/10.1016/j.foodchem.2018.02.139

Bobko, M., Haščík, P., Kročko, M., Trembecká, L., Mendelova, A., Tkáčová, J., Tóth, T. 2017. Effect of grape seed extract on quality of raw-cooked meat products. Potravinarstvo, vol. 11, no. 1, p. 517-521. https://doi.org/10.5219/797

Bobko, M., Haščík, P., Tóth, T., Kňazovická, V., Mellen, M., Bobková, A., Tkáčová, J. 2015. Oxidative stability of chicken meat after application phytogenic additives in their diet. Journal of Microbiology, Biotechnology and Food Sciences, $\begin{array}{lllll}\text { vol. } 4 & \text { no. } & 3, & \text { p. } & 1417 .\end{array}$ https://doi.org/10.15414/jmbfs.2015.4.special3.14-17

Cabrera, M. C., Saadoun, A. 2014. An overview of the nutritional value of beef and lamb meat from South America. Meat Science, vol. 98, no. 3, p. 435-444. https://doi.org/10.1016/j.meatsci.2014.06.033

Commission Delegated Regulation (EU) 2017/1182 of 20 April 2017 amending Regulation (EU) No 182/2011 of the European Parliament and of the Council Amending Regulation (EC) No 1308/2013 as regards the Union scale for the classification of carcases of bovine animals, swine and sheep and the notification of market prices for other types of carcases and live animals.

Crăciun, O. C., Lazăr, R., Boişteanu, P. C. 2012. Research regarding the biological value of meat protein from sheep. Lucrări Ştiinţifice-Seria Zootehnie, vol. 57, p. 55-60.

Cruxen, C. E. S., Braun, C. L. K., Fagundes, M. B., Gularte, M. A., Wagner, R., Padilha da Silva, W., Fiorentini, Â. M. 2018. Development of fermented sausage produced with mutton and native starter cultures. $L W T$, vol. 95, p. 23-31. https://doi.org/10.1016/j.lwt.2018.04.060

Cunha, L. C. M., Monteiro, M. L. G., Lorenzo, J. M., Munekata, P. E. S., Muchenje, V., de Carvalho, F. A. L., ConteJunior, C. A. 2018. Natural antioxidants in processing and storage stability of sheep and goat meat products. Food Research International, vol. 111, p. 379-390. https://doi.org/10.1016/j.foodres.2018.05.041

Čuboň, J., Cviková, P., Haščík, P., Kačániová, M., Kunová, S., Hleba, L., Bobko, M., Trembecká, L., Bučko, O., Tkáčová. J. 2017. The proteins degradation in dry cured meat and methods of analysis: a review. Journal of Microbiology, Biotechnology and Food Sciences, vol. 7 , no. 2, p. 209-220. https://doi.org/10.15414/jmbfs.2017.7.2.209-220

Čuboň, J., Haščík, P., Pavelková, A., Tkáčová, J., Hleba, L., Bučko, O., Jarošová, A., Cisárová, M. 2019. Protein degradation and fat oxidation changes in salted meat processing. Journal of Microbiology, Biotechnology and Food Sciences, $\quad$ vol. $\quad 9, \quad 376-379$. https://doi.org/10.15414/jmbfs.2019.9.special.376-379

Čuboň, J., Kačániová, M., Kunová, S., Haščík, P., Hleba, L., Bebejová, A., Šmýkalová, H. 2015. Analysis of free amino acids and biogenic amines in the bull Musculus thoracis. Journal of Microbiology, Biotechnology and Food Sciences, vol. 4, no. 3, p. 27-30. https://doi.org/10.15414/jmbfs.2015.4.special3.27-30

Faustman, C., Suman, S. P. 2017. The Eating Quality of Meat. In Toldrá, F. Lawrie's Meat Science. Duxford, United Kingdom : Woodhead Publishing, p. 329-356. ISBN 9780081006979. https://doi.org/10.1016/b978-0-08-100694$\underline{8.00011-\mathrm{X}}$

Feng, X., Tjia, J. Y. Y., Zhou, Y., Liu, Q., Fu, C., Yang, H. 2020. Effects of tocopherol nanoemulsion addition on fish sausage properties and fatty acid oxidation. $L W T$, vol. 118, p. 108737. https://doi.org/10.1016/j.lwt.2019.108737

Holland, B., Welch, A. A., Unwin, I. D., Buss, D. H., Paul, A. A., Southgate, D. A. T. 1991. McCance and Widdowson's the composition of foods. $5^{\text {ed }}$. UK : Royal Society of Chemistry, 462 p. ISBN 9780851863917.

Huang, C., Chiba, L. I., Magee, W. E., Wang, Y., Rodning, S. P., Bratcher, C. L., Bergen, W. G., Spangler, E. A. 2020. Effect of flaxseed oil, poultry fat, and vitamin $E$ supplementation on physical and organoleptic characteristics and fatty acid profile of pork, and expression of genes associated with lipid metabolism. Livestock Science, vol. 231, p. 103849. https://doi.org/10.1016/j.livsci.2019.103849

Cheng, C., Liu, Z., Zhou, Y., Wei, H., Zhang, X., Xia, M., Peng, J. 2017. Effect of oregano essential oil supplementation to a reduced-protein, amino acid-supplemented diet on meat quality, fatty acid composition, and oxidative stability of Longissimus thoracis muscle in growing-finishing pigs. Meat Science, vol 133, p. 103-109. https://doi.org/10.1016/j.meatsci.2017.06.011

Chikwanha, O. C., Vahmani, P., Muchenje, V., Dugan, M. E. R., Mapiye, C. 2018. Nutritional enhancement of sheep meat fatty acid profile for human health and wellbeing. Food Research International, vol. 104, p. 25-38. https://doi.org/10.1016/j.foodres.2017.05.005 
Jia, G., Sha, K., Feng, X., Liu, H. 2019. Post-thawing metabolite profile and amino acid oxidation of thawed pork tenderloin by HVEF-A short communication. Food Chemistry, vol. 291, p. 16-21. https://doi.org/10.1016/j.foodchem.2019.03.154

Jung, S., Nam, K. C., Jo, C. 2016. Detection of malondialdehyde in processed meat products without interference from the ingredients. Food chemistry, vol. 209, p. 90-94. https://doi.org/10.1016/j.foodchem.2016.04.035

Kim, D. H., Seong, P. N., Cho, S. H., Kim, J. H., Lee, J. M., Jo, C., Lim, D. G. 2009. Fatty acid composition and meat quality traits of organically reared Korean native black pigs. Livestock Science, vol. 120, no. 1-2, p. 96-102. https://doi.org/10.1016/j.livsci.2008.05.004

Krishtafovich, V., Krishtafovich, D., Surzhanskaya, I., Marakova, A., Vorobieva, D. 2016. The value of the lamb meat in human nutrition. International Food Research Journal, vol. 23, no. 6, p. 2540-2544.

Marcinčák, S., Popelka, P., Bystrický, P., Hussein, K., Hudecová, K. 2005. Oxidative stability of meat and meat products after feeding of broiler chickens with additional amounts of vitamin E and rosemary. MESO: Prvi hrvatski časopis o mesu, vol. 7, no. 1, p. 34-39. Available at: https://hrcak.srce.hr/22586.

Marti-Quijal, F. J., Zamuz, S., Tomašević, I., Gómez, B., Rocchetti, G., Lucini, L., Remize, F., Barba, F. J., Lorenzo, J. M. 2019. Influence of different sources of vegetable, whey and microalgae proteins on the physicochemical properties and amino acid profile of fresh pork sausages. $L W T$, vol. 110, p. 316-323. https://doi.org/10.1016/j.lwt.2019.04.097

Ning, C., Li, L., Fang, H., Ma, F., Tang, Y., Zhou, C. 2019. 1-Lysine/l-arginine/l-cysteine synergistically improves the color of cured sausage with $\mathrm{NaNO} 2$ by hindering myoglobin oxidation and promoting nitrosylmyoglobin formation. Food Chemistry, vol. 284, p. 219-226. https://doi.org/10.1016/j.foodchem.2019.01.116

Nowak, K. W., Markowski, M., Daszkiewicz, T. 2016. A modified ultrasonic method for determining the chemical composition of meat products. Journal of Food Engineering, vol. $180, \quad$ p. $10-15$. https://doi.org/10.1016/j.jfoodeng.2016.02.010

Poráčová, J., Koréneková, B., Sedlák, V., Konečná, M. 2017. Základné zložky potravy a ich význam pre zdravie človeka (Basic components of food and their importance for human health). Prešov, Slovakia : Prešovská univerzita v Prešove, $\mathrm{p}$. 11-27. ISBN 978-80-5551839-8. (In Slovak)

Reitznerová, A., Šuleková, M., Nagy, J., Marcinčák, S., Semjon, B., Čertík, M., Klempová, T. 2017. Lipid Peroxidation Process in Meat and Meat Products: A Comparison Study of Malondialdehyde Determination between Modified 2Thiobarbituric Acid Spectrophotometric Method and ReversePhase High-Performance Liquid Chromatography. Molecules, vol. 22, no. 11, p. 1988. https://doi.org/10.3390/molecules22111988

Rudy, M. 2009. 2009. The Analysis of Correlations Between the Age and the Level of Bioaccumulation of Heavy Metals in Tissues and the Chemical Composition of Sheep Meat from the Region in SE Poland. Food and Chemical Toxicology, vol. 47, no. 6, p. 1117-1122. https://doi.org/10.1016/j.fct.2009.01.035

Šojić, B., Tomović, V., Kocić-Tanackov, S., Škaljac, S., Ikonić, P., Džinić, N., Živković, N., Jokanović, M., Tasić, T., Kravić, S. 2015. Effect of nutmeg (Myristica fragrans) essential oil on the oxidative and microbial stability of cooked sausage during refrigerated storage. Food Control, vol. 54, p. 282-286. https://doi.org/10.1016/j.foodcont.2015.02.007
Tsikas, D. 2017. Assessment of lipid peroxidation by measuring malondialdehyde (MDA) and relatives in biological samples: Analytical and biological challenges. Analytical Biochemistry, vol. 524, p. 13-30. https://doi.org/10.1016/j.ab.2016.10.021

Williams, P. 2007. Nutritional composition of red meat. Nutrition \& Dietetics, vol. 64, no. 4, p. S113-S119. https://doi.org/10.1111/j.1747-0080.2007.00197.x

\section{Funds:}

The work was prepared with the support of the project KEGA 027SPU-4/2019 and Demand-Oriented Research for Sustainable and Innovative Foods, Drive4SIFood 313011V336, co-financed by the European Regional Development Fund.

\section{Conflict of Interest:}

The authors declare no conflict of interest.

\section{Ethical Statement:}

This article does not contain any studies that would require an ethical statement.

\section{Contact Address:}

*Juraj Čuboň, Slovak University of Agriculture, Faculty of Biotechnology and Food Sciences. Department of Technology and Quality of Animal Products, Tr. A. Hlinku 2, 94976 Nitra, Slovakia, +421 37641 4709,

E-mail: juraj.cubon@uniag.sk

ORCID: https://orcid.org/0000-0002-1388-1527

Peter Haščík, Slovak University of Agriculture, Faculty of Biotechnology and Food Sciences. Department of Technology and Quality of Animal Products, Tr. A. Hlinku 2, 94976 Nitra, Slovakia, +421 37641 4708,

E-mail: peter.hascik@uniag.sk

ORCID: https://orcid.org/0000-0002-3402-5658

Peter Herc, Slovak University of Agriculture, Faculty of Biotechnology and Food Sciences. Department of Technology and Quality of Animal Products, Tr. A. Hlinku 2, 94976 Nitra, Slovakia,

E-mail: peter.herc96@gmail.com

ORCID: https://orcid.org/0000-0002-2366-8324

Lukáš Hleba, Slovak University of Agriculture, Faculty of Biotechnology and Food Sciences, Department of Microbiology, Tr. A. Hlinku 2, 94976 Nitra, Slovakia, +421376415811,

E-mail: lukas.hleba@gmail.com

ORCID: https://orcid.org/0000-0001-8244-6548

Miroslava Hlebová, University of SS. Cyril and Methodius, Department of Biology, Faculty of Natural Sciences, Nám. J. Herdu 2, SK-91701 Trnava, Slovakia,

E-mail: miroslava.hlebova@gmail.com

ORCID: https://orcid.org/0000-0002-1720-9981

Nikoleta Šimonová, Slovak University of Agriculture, Faculty of Biotechnology and Food Sciences. Department of Animal Physiology, Tr. A. Hlinku 2, 94976 Nitra, Slovakia,

E-mail: xsimonovan1@uniag.sk

ORCID: https://orcid.org/0000-0002-8217-2521 
Ondřej Bučko, Slovak University of Agriculture, Faculty Corresponding author: * of Biotechnology and Food Sciences. Department of Technology and Quality of Animal Products, Tr. A. Hlinku 2, 94976 Nitra, Slovakia, Tel.: +421 37641 4802,

E-mail: ondrej.bucko@uniag.sk

ORCID: https://orcid.org/0000-0001-6942-511X 